\title{
The contradictions in the views of Russian conservative philosophers (Nikolay Strakhov, Konstantin Leontiev and Petr Astafiev) on philosophical and literary value of L. N. Tolstoy Avdeev 0. \\ Противоречия во взглядах представителей русского консерватизма (Н. Н. Страхова, К. Н. Леонтьева и П. Е. Астафьева) на философское и литературное значение Л. Н. Толстого Авдеев О. К.
}

\author{
Авдеев Олег Константинович / Avdeev Oleg - кандидат философских наук, \\ кафедра истории русской философии, философский факультет, \\ Московский государственный университет имени М. В. Ломоносова
}

\begin{abstract}
Аннотация: в статье анализируются несовпадения во взглядах Н. Н. Страхова, К. Н. Леонтьева и П. Е. Астафьева на литературное наследие и философское мировоззрение Л. Н. Толстого, а также факты печатной и личной полемики между ними по этому вопросу. При этом анализируется публицистическое и эпистолярное наследие указанных авторов. В статье делается вывод о нефундаментальном характере противоречивой оценки Л. Н. Толстого в русском консерватизме.

Abstract: the article analyzes the controversy in the views of Nikolay Strakhov, Konstantin Leontiev and Petr Astafiev on the literary heritage and the philosophical worldview of Leo Tolstoy and the facts of their personal and printed polemics on this issue. Author analyzes the journalistic and epistolary heritage of these authors. The conclusion the article confirms the non-fundamental nature of the controversial appraisal of Leo Tolstoy in Russian conservative philosophy.
\end{abstract}

Ключевые слова: история русской философии, русский консерватизм, консерватизм, Н. Н. Страхов, К. Н. Леонтьев, П. Е. Астафьев, Л. Н. Толстой.

Keywords: history of Russian philosophy, Russian conservative philosophy, conservatism, Nikolay Strakhov, Konstantin Leontiev, Petr Astafiev, Leo Tolstoy.

Близость социально-политических взглядов ряда представителей отечественной консервативной общественной мысли второй половины XIX века (в том числе: в оценке роли православия и самодержавия в российской государственности, в поиске новых путей сохранения русской идентичности, в оценке значений индивидуальности в истории, философском органицизме, цивилизационной интерпретации исторического процесса, известной, по терминологии $Н$. Я. Данилевского, как культурно-исторический подход и т.п.), Н. Я. Данилевского, Н. Н. Страхова, К. Н. Леонтьева, П.Е. Астафьева, А. А. Григорьева и других, а также наличие у их социальнополитических и публицистических текстов философской основы, позволяет рассматривать их как отдельное течение в русской мысли. При этом это течение не является «идеальной» исследовательской конструкцией, но представляет собой вполне реальный круг общения, объединенный не только комплексом идей, но и личными связями, дружескими или же враждебными отношениями (которые, впрочем, никогда не ставились выше идейной близости), близостью к редации изданий М. Н. Каткова «Русский вестник» и «Московские ведомости», скрытой и явной полемикой по центральным вопросам консервативного мировоззрения - как при личных встречах, так и в печати.

При этом сами перечисленные мыслители осознавали эту близость и принадлежность к единому течению. В частности, в своём письме Страхову от 1887 года Леонтьев перечислил список главных книг (и авторов) русской консервативной мысли: «Молодые люди ищут, бьются, и нет «России и Европы» (я об этой книге говорю). Для меня один юноша свою, всю растрёпанную от чтения, подарил. Ваша «Борьба с Западом» (по-моему «Самоосуждение Запада») тоже, говорят, очень стала читаться. Мой сборник «Восток, Россия и славянство» министр народного просвещения представил Государю!» [3, c. 302]. Страхов активно защищал в печати историософскую концепцию Данилевского от нападок Вл. С. Соловьёва. А. Астафьев в работе «Смысл истории и идеалы прогресса» констатировал сходство взглядов Леонтьева на историю с собственной позицией. Особой его похвалы удостоило то, что Леонтьев продемонстрировал «противоположность развитию прогресса (эгалитарно-либерального, утилитарного, космополитического etc.), который, однако, самим же процессом развития в известный момент человеческой жизни вызывается, полагая конеи дальнейшему развитию и - начало разложению, общественной и культурной смерти» [1, с. 23].

В то же время, между указанными авторами имела место жесткая полемика по ряду ключевых для консервативного «стиля мышления» (по выражению К. Маннгейма), как в переписке друг с другом и с 
другими корреспондентами, так и в печати. Одним из предметов полемики между представителями русского консерватизма была оценка взглядов и художественного творчества Л. Н. Толстого.

В частности можно говорить о скрытой полемике между Страховым и Астафьевым - по поводу значения и пользы религиозно-философского учения Л. Н. Толстого. В своих критических статьях [9], посвящённых творчеству Толстого, Страхов не только анализировал и разъяснял читающей публике его произведения, но и пытался выступить апологетом его учения, защищая против нападок. Не будучи в полной мере согласным с Толстым, Страхов, тем не менее, защищал его в сборнике «Критические статьи об И. С. Тургеневе и Л.Н. Толстом» [10] и вообще при всяком удобном случае устно и письменно вступался за него. Такой подход вызвал явное неудовольствие Астафьева, причислявшего учение Толстого к наиболее вредным влияниям своего времени, искажавшим нарождающееся возвращение религии в духовную жизнь общества. Особенно недоумевал он из-за того, что «оно оказало такое огромное и глубокое умственное влияние, увлекая за собою все далее и далее от догматических и мистических основ христианства, не только на незрелые умственно, но искренне чувствующие неправду в своей жизни и ищущие из неё выхода, полуобразованные и преимущественно юные массы, но и на вполне умственно-зрелых людей, становящихся его апологетами, вроде, например, Н. Н. Страхова» [2, с. 364]. Причиной этого он видит распространившуюся повсеместно «позитивистскую» тенденцию сводить значение религии к посюсторонней нравственности, влияния которой Страхов не избежал и которая «слишком явно сказывается в очевидных натяжках, софизмах его апологии гр. Толстого» [2, с. 365].

Не сошелся Страхов в своей оценке Толстого и с Леонтьевым. Например, если Страхов боготворил Л. Н. Толстого как писателя и как человека, и даже забывчивость и невнимательность к себе писателя оправдывал, находя (в письме В. В. Розанову), что «великое достоинство эта нераздельная преданность одной мысли» [7, с. 63], то Леонтьев, признавая Толстого одним из лучших русских писателей, возмущался языком («гадкие слова натуральной школы» [3, с. 52]) и стилистикой реалистической литературы. В письме Страхову он так характеризует Толстого: «Ваш Толстой хорошо рисует пунктиками на слоновой кости; но кисть его всегда мелка, как бы ни были велики события, за которые он берётся. Теплоты у него, быть может, много в сердце, но он не умеет излить эту теплоту на бумагу широкими воздушно-героическим и чертами» [3, с. 70]. И даже в лучшем, по его мнению, произведении Толстого, «Анне Карениной», которую он, по собственному признанию, прочитал три раза (едва ли не больше, чем Страхов), видятся ему «ненужные и противные выходки, от которых никто из наших писателей со времён Гоголя избавиться вполне не мог» [4, с. 80], а именно - настойчивые «снижающие» детали, примеры которых Леонтьев приводит: «как изирюльник бреет Облонского, как раздался носовой свист (как это пошло, гадко, и главное, не нужно) мужа Карениной... Как граф Вронский надвигал фуражку свою на свою рано оплешивевшую голову, и как он поливал водой свою здоровую красную шею» [4, с. 80]... Пересказывая этот анализ Леонтьевым Толстого в работе «Эстетическое понимание истории», Розанов характеризует его как «всегда убедительный, проникнутый любовью, но уже и отчуждающийся суд, который произносит г. Леонтьев над высшими проявлениями нашей натуральной школы» [8, с. 33]. Страхов, напротив, в письме самому Толстому, хвалит за детализацию «этот чистый, ясный, как кристалл, рассказ, в котором всё видишь, как на картине, где всё и верно и ново, производит вполне всё то неотразимое действие, какое свойственно художеству» [6, с. 58].

И, конечно, Леонтьев не признавал взглядов Толстого на культуру и религию и даже (не без юмора) поминал это в своих письмах к Страхову. Так, в одном из писем к нему он призывает «радоваться и благодарить Бога (только не Лев-Толстовского Бога, а Оптинского, настоящего...)» [3, с. 302-303], в другом - любопытствует об истинных, личных («для себя») религиозных взглядах Страхова («Дорого бы я дал - чтобы наверное узнать, - что Вы в самом деле думаете об этих вещах... Неужели Вы остановились на Православии в культурном смысле для других и на интимном пантеизме для себя? <..> признаюсь только, что ужасно желал бы забраться на минуту в серое вещество Вашего обширного, судя по фотографиям, мозга или даже ещё дальше, в какой-нибудь Ваш вартолиев мост..!» [3, с. 116]), а в 1891 году в черновике неотправленного письма можно встретить такой экспрессивный фрагмент: «...уж простите, Христа ради, да и то, если для Вас Христос не «легенда», и в самом деле Бог, которого Вы боитесь, если же нет, как по многим признакам мне подозревается, то и прощения-то не стоит у Вас просить; а не велик грех будет и в тартарары Вас проводить вместе с ( ～） и Л. Н. Толстым» [3, с. 527] (первое имя пропущено в тексте самим Леонтьевым).

В то же время, в свое время Леонтьев был не чужд симпатии к Толстому, которого мечтал «заманить» в газету «Варшавский дневник», с которой сотрудничал, и которому даже писал письмо с просьбой написать для них что-нибудь. В этом письме он даже воспроизводит свой диалог с издателем «Варшавского дневника» князем Голициным, которому Леонтьев, по его словам, ответил на скепсис в отношении Толстого: «Про Графа Толстого я думаю иначе. <...> для него прежде всего искренность $u$ сила убеждений нужна» [5, с. 770].

Любопытно, что если в отношении Толстого Леонтьев ограничивается стилистической критикой, совпадая со Страховым в высокой оценке его личности и таланта, то, например, в отношении 
И. С. Тургенева мнения их диаметрально противоположны по всем возможным аспектам. Сравнивая себя с этим писателем (некогда ему покровительствовавшим в начале литературного пути), Леонтьев находит, что «...Тургенев вовсе не стоит своей репутации. Быть выше Тургенева - это ещё не много. Не велика претензия. Один язык его для человека понимающего, что такое язык сильный (Гоголь, Щедрин) или язык изящный (Пушкин, Грановский, старик С. Аксаков, Марко Вовчок), один язык Тургенева, никогда ни сильно-грубый, ни изящно-простой, ни увлекательно-цветистый, а какой-то мелочный и дряблый, может вызвать отвращение. Особенно «Записки охотника»» [3, с. 184].

В целом полемика между представителями русского консерватизма шла скорее об аспектах, чем о сути их взглядов. В частности, в отношении философских взглядов Толстого Страхов выступает последовательным апологетом (на правах редактора и близкого друга) творчества Толстого и очень аккуратно, а местами также апологетически, отзывается в печати о его учении (не соглашаясь с Толстым в частной переписке), в то время как Астафьев прямо порицает религиозно-философские взгляды Толстого, рассматривая их как опасное извращение религиозного сознания, а Леонтьев обрушивается с критикой не только на них, но и на его художественное творчество в рамках своей критики реалистического направления в литературе.

\section{Лuтература}

1. Астафьев П. Е. Смысл истории и идеалы прогресса: Две публ. лекции, чит. в Москве 15 и 17 марта 1885 г. М.: тип. Л. Ф. Снегирева, 1885. 62 с.

2. Астафьев П. Е. Философия нации в единстве мировоззрения. М.: Москва, 2000. 544 с.

3. Леонтьев К. Н. Избранные письма: 1854-1891. СПб.: Пушкинский фонд, 1993. 637 с.

4. Леонтьев К. Н. Моя литературная судьба. Воспоминания. М.: Русская книга, 2002. С. 80.

5. Леонтьев К. Н. Полн. собр. соч. и писем: В 12 т. СПб.: Владимир Даль, 2003. Т. 7 (2). 1022 с.

6. Переписка Л. Н. Толстого с Н. Н. Страховым: 1870-1894. СПб.: Об-во Толстовского музея, 1914. 478 c.

7. Розанов В. В. Литературные изгнанники: Н. Н. Страхов, К. Н. Леонтьев. М.: Республика, 2001. 475 с.

8. Розанов В. В. Эстетическое понимание истории // К. Н. Леонтьев: pro et contra. В 2-х книгах. СПб.: Издательствово РХГИ, 1995. Кн. І. С. 27-122.

9. Страхов Н. Н. Толки об Л. Н. Толстом (Психологический этюд). // Вопросы философии и психологии. М., 1891. Год ІІ. Кн. 9. С. 98-132.

10. Страхов Н. Н. Критические статьи об И. С. Тургеневе и Л. Н. Толстом: 1862-85. СПб.: Тип. бр. Пантелеевых, 1885. 484 с. 